\title{
WHO IS SYLVIA?
}

\section{Claire Harman}

(From Lives for Sale: Biographers' Tales, ed. Mark Bostridge, Continuum, 2004)

There is a strong sense of transgression in all its meanings, in the process of researching the life of another person. The kind of attention and effort one devotes to it, the obsessive pursuit of data and peripheral information is greater than anyone (apart from an aristocrat, perhaps) would ever devote to their own history. As a consequence, you get to know your subject's life in a way they never did. You know their greatgrandparents' birth dates, the middle names of their schoolmasters, the date at which their final illness commenced. And as the picture builds up, so the biographer feels more and more omniscient: having read not only the subject's diaries and love letters, wills and shopping lists, but everyone else's connected with the story too, he feels in a unique position to judge the facts of the case, knowing so much about it.

This sense of having special knowledge often promotes fanciful identifications between the biographer and his or her subject. It is a dominant theme in fictions about biography, which usually show a researcher falling under a sort of spell, having his or her personality taken over by that of the subject. A. S. Byatt's Possession is a sentimental example, where one of the characters, having been drawn to study the work of an obscure nineteenth-century woman poet, discovers an actual blood connection between herself and the subject, surely the 
ultimate biographer's fantasy. Henry James's short story of 1899, 'The Real Right Thing', takes a more critical approach: in it, the young biographer character, George Withermore, is preparing to write the life of a recently dead author whose work he has idolized. He is overcome by the thrill and honour of being left alone with the dead man's papers, but the more the biographer goes into the archive, the greater is his sense of wrong-doing: he feels the writer's ghost straining forward and 'making dim signs out of his horror', and - not surprisingly - takes this as a sign that he should give up the project.

James's own anxieties about becoming the subject of a biography are fully evident in that story, as in others, such as The Aspern Papers, which ends with the destruction of Jeffrey Aspern's love letters by Miss Tina, who blithely says to the stricken scholar, 'What was I to keep them for?' The Miss Tina standpoint is not necessarily a philistine one - the narrator of the story notes (just before he hears the news about the papers) that she has somehow acquired 'the force of soul' and Miss Tina herself refers to the burning as having done 'the great thing'. Other Miss Tinas in literature are often depicted directly or indirectly preserving the integrity of the past, such as the great man's lover in Auden's poem 'Who's Who' who astonishes critics by keeping none of the subject's 'long marvellous letters'.

I'm glad now that I didn't meet the subject of my first book, Sylvia Townsend Warner, who died four years before I was asked to writer her biography. It meant she never got the chance to dislike me or disapprove of my appointment, whereas I was rewarded by what Withermore in 'The Real Right Thing' describes as 'the possibility of an intercourse closer than that of life'. Warner displayed admirable fatalism about her posterity, destroying a few papers, leaving in order the love letters she wanted published, pretty much neglecting everything else. She left no instructions about her diaries but must have guessed that someone would think them publishable one day; all the same, I felt extremely intrusive when I began to read them. Sylvia was one of what Michael Holroyd calls 'the warm dead'; I was the first person to go 
through her papers which had been removed by the trustees from her house (still occupied by a friend of the deceased) and stored in an attic at the Dorset County Museum. The museum had a bit of a problem, it seemed, with bequests. The works of Elizabeth Muntz, sculptress, had also been left them at approximately the same time and whenever I tried to get up the back stairs to the garret where the Warner archive was housed, more and more Muntz seemed to have strayed onto the landings.

I had come across Warner's work originally in a way that emphasized this aura of neglect, finding a package of her poems under a desk in the publisher's office where I worked in 1979. They had been left to the publisher by the author, but 18 months after Warner's death, no one had yet done anything about them. The only thing that had sent me under the desk in the first place was one of those odd hormonal rushes of late pregnancy that impel women to meet severe cleaning challenges, but when I took the poems home (I had never heard of Warner), I found the material so unusual and puzzling that by the time I went into labour a few weeks later, the book I took with me was Lolly Willowes, one of only three Warner novels then in print. By the middle of the next year, I was totally engrossed with the subject, had bought as many first editions as possible, had contacted the estate, the friends, put together a celebration of her work, edited the poems, changed the subject of my $\mathrm{PhD}$. I was delighted when Warner's executors asked me to write the biography, of course, but also rather intimidated. Up to this point I had been studying Warner (a writer who had entirely evaded the canon); researching her life and making judgements about her personality would be an entirely different matter.

It was at this point that I began to have access to the things in the garret, the photos and love tokens, diaries and letters, books and dolls, old gardening shoes, the death mask (creepily waiting to peek-a-boo from a shoe box). No one else was the least bit interested in them at that date, and of course after a while, I felt that they were somehow meant for me, that I was a sort of self-appointed granddaughter to this childless woman, the keeper of the flame. Within a short time I could 
recognize, from references in the diaries, the significance and provenance of many of the objects in the collection, and turning to the job-lot of supposedly worthless books from the Frome Vauchurch library (acquired for me by a watchful dealer) found that the Prayer Book I had bought was the very one, embossed on the spine with the name 'Mrs Johnson', that Sylvia and her beloved Valentine used to do sortes Virgilianae in when they were first in love. Inside the book was a tear-off calendar slip used as a bookmark: 12 January 1932. I knew what this date commemorated, and that no other living person would know it. Such things certainly encourage the Possession factor. No 'ghosts making dim signs out of their horror' for me: if anything, I felt led on and encouraged. Even the death mask seemed to be smiling.

I was aware at the same time of a profound impertinence, especially in my necessary approaches to the many friends who had survived Sylvia. For a start, I looked wrong - or unlikely. I was only 24; married, a mother once over, pregnant with my second child. As I waddled up the drive of Sylvia's house at Frome Vauchurch in a rose-patterned maternity dress with puff sleeves, carrying the two milk bottles I had found by the gate, I was conscious of presenting a mildly ludicrous picture to the woman inside the house, looking out from behind the curtains as she always did. When I say 'I must have' I really mean I know I did, as the curtain-twitcher later told the woman who was to be her last lover that the position in which I was carrying the milk bottles, one under each pregnant breast, she found inexpressibly comical.

The lady in the house had a mischievous disposition, and enjoyed making me uncomfortable, serving me an aspic for tea that contained mostly cat hair (the aspic itself I now suspect was a joke reference to the processes of biography), answering questions with a prolonged silent stare. Her mild aggressiveness was understandable enough. Natasha Spender, widow of the poet, has written from bitter experience of the position in which friends and family of biographical subjects, faced with a letter from an unknown researcher, find themselves: 'It is better to grant an interview to this stranger, about whose motives, intelligence and goodwill they can as 
yet know nothing, and whose probity they must take on trust, because their own knowledge can contribute to the truth of the book, and truth is preferable.' The things that Sylvia's friends told me rarely, if ever, had much value for my research (unless they kept to data, which none did); the function of my visits to them was social rather than biographical, and the unspoken subject not Sylvia's secrets but whether or not I was a suitable custodian of them. Since that choice had already been made by the estate, both the friends and I had to live with it, and while most of them were more than gracious about the situation, generous with their friendship, trust and memories, others gave off signals of suspicion and sufferance that you could have cut with a cake-fork.

I stayed in the deathbed, I acquired some books, some furniture, many kind friends, but I always knew the special relationship with Sylvia Towsend Warner would date and fade. Back at Frome Vauchurch a real-life Miss Tina moved in who also felt destined to be a keeper of the flame - the bonfire flame - and who despatched wholesale whatever she could find in Sylvia's handwriting, believing Warner to have been a witch. Things were in flux: the Warner archive began to be catalogued: the diaries that I had felt it was a transgression, an impertinence, to open a few years before, became available in print. A literary society was formed; it performs ceremonies around the grave on the anniversary of Warner's death.

The first biographer of a subject forms the story, establishes the shape of the life. With a subject who is recently dead, you also generate material through the soliciting of reminiscences and opinions and begin, almost inevitably, to interact with the story yourself. Even before my book was finished, I noticed my own handwriting in the Chatto \& Windus archive at Reading University - letters I had written to Norah Smallwood, Sylvia's publisher, that had already become a part of the story I was trying to uncover, I was suddenly aware of the barrier between life and life writing, but which side was I on?

The most affecting of the photographs I brought back from Samoa when researching my most recent book on Robert 
Louis Stevenson, was the one showing the verandah on which he died, with my own sandals in the foreground, obediently removed on the instructions of the museum's staff. There is something innocent and untainted about their presence. Unlike the biographer, they weren't trying to insert themselves in the picture. They got onto that verandah meaninglessly, like things in Stevenson's past, and I look at those sandals now with a sort of jealousy. 